\title{
Nanoszerkezetü anyagok alkalmazása a szenzor fejlesztés, az olajipar, a gyógyszerkutatás és a heterogén katalízis területén
}

\author{
CSAPÓ Edit ${ }^{\mathrm{a}, \mathrm{b}^{*}}$, SEBÖK Dániel ${ }^{\mathrm{a}}$, JANOVÁK Lászlóa, JUHÁSZ Ádám ${ }^{\mathrm{a}, \mathrm{b}}$ és DÉKÁNY Imre ${ }^{\mathrm{a}}$ \\ ${ }^{a}$ Szegedi Tudományegyetem, Fizikai Kémiai és Anyagtudományi Tanszék, Dóm tér 8, 6720 Szeged, Magyarország \\ ${ }^{b}$ MTA-SZTE Biomimetikus Rendszerek Kutatócsoport, Dóm tér 8, 6720 Szeged, Magyarország
}

\section{Bevezetés}

A Szegedi Tudományegyetem Természettudományi és Informatikai Karának, Fizikai Kémiai és Anyagtudományi Tanszékén működő Kolloidok és Nanoszerkezetü Anyagok Kutatócsoportunk kutatási profilja a csoport közel 25 éves fennállása óta számos területet érintett. A rétegszilikátok és réteges kettős hidroxidok $(\mathrm{LDH})$ által stabilizált félvezető nanorészecskék méretszabályozott szintézise mellett az ultravékony hibrid filmek és az anizometrikus nanolamellás rendszerekből felépíthető önszerveződő kolloid rendszerek tanulmányozása is szerves részét képezte kutatásainknak. A Dékány Imre akadémikus által vezetett kutatócsoport eredményei több könyvfejezetben és nemzetközileg rangos folyóiratokban közel 250 publikáció formájában kerültek bemutatásra, emellett 5 szabadalmi bejelentés is született 1990-2016 között. A Szegedi Tudományegyetem ÁOK Orvosi Vegytani Intézetben 2007-2017 között az MTA-SZTE Szupramolekuláris és Nanoszerkezetü Anyagok Kutatócsoportban interdiszciplináris kutatásokat végeztünk kémiai, biológiai és orvosi szakterületeken alkalmazott kutatási módszerek együttes alkalmazásával. A nanoszerkezetü anyagok vizsgálatában alkalmazott kísérleti technikák által szolgáltatott információk, sikeresen hozzájárultak peptidek és fehérjék élettani jelentőségü sajátságainak modellezéséhez és megismeréséhez. Ezáltal olyan neurodegeneratív kórképek molekuláris szintü kialakulásának feltérképezésében tudtunk eredményeket elérni, mint például az Alzheimer-kór, amely egyike a fehérjék szerkezetváltozásával összefüggő betegségeknek. A csoport 2017. júliustól megújult kutatási programmal, kibővült müszerparkkal és átszervezett személyi állománnyal MTA-SZTE Biomimetikus Rendszerek Kutatócsoport néven tevékenykedik tovább Prof. Dr. Tóth Gábor vezetésével. Az említett kutatócsoportjaink fóbb kutatási eredményeit a következőekben foglaljuk össze.

\section{Szilárd - gáz határfelületek: Vékonyrétegek előállítása és szenzorikai alkalmazása}

Kutatócsoportunkban már több évtizedes múltra tekint vissza a vékonyrétegek különböző módszerekkel történő előállítása és sokrétü alkalmazása. Előbbiek közül a legismertebbek a Langmuir-Blodgett filmek, valamint az úgynevezett LbL (angol: Layer-by-Layer, rétegröl-rétegre) technikával készített vékonyrétegek, melynek preparálása során ellentétes felületi töltéssel rendelkező polielektrolitokat, agyagásványokat és nanorészecskéket alkalmazunk, mint „építőelemeket”. Ezek váltakozó adszorpciója, adhéziója által igen változatos szerkezetű és jól kontrollálható paraméterekkel (pl. rétegszám, rétegvastagság, törésmutató, porozitás stb.) rendelkező filmek állíthatók elő (1. ábra).

A későbbi alkalmazások, felhasználási módok túlnyomó többsége során elengedhetetlen a vékonyrétegek főbb paramétereinek ismerete. A szenzorikai célú alkalmazások esetében ezek a rétegvastagság, törésmutató, porozitás. Ezek megismerése során az 1.A ábrán látható sémák alapján elsőként szerkezeti modellt állíthatunk fel, majd abban alkalmazzuk a fény, hullám- és sugár-terjedési sajátságait leíró törvényszerüségeket (pl. fénytörés, visszaverődés, interferencia).
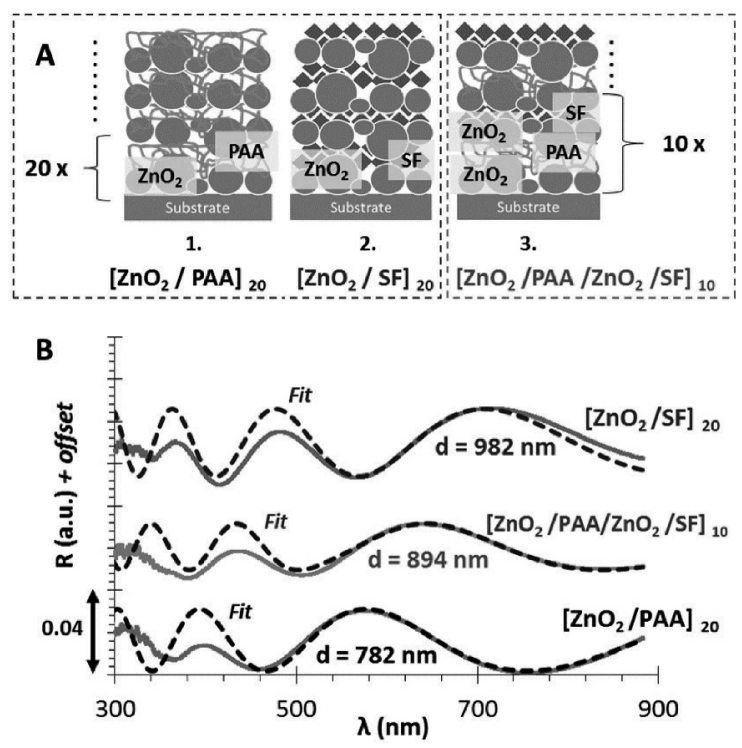

1. Ábra. $L b L$ technikával készített vékonyrétegek változatos szerkezetét bemutató sematikus ábra (A), valamint az így elöállított filmek rétegvastagságának meghatározása a róluk visszaverődött (fehér) fény spektrumának analízisével (B).

Az így nyert, a visszavert fény spektrumát jellemző hullámhosszfüggő, és a kérdéses paramétereket tartalmazó egyenletet a mérési adatainkhoz igazítva kapjuk például a film rétegvastagságát $(d, 1 . \mathrm{B}$ ábra) és törésmutatóját $(n)$. A törésmutató azért kap kitüntetett figyelmet, mert az érzékelő vékonyréteg felületen vagy annak pórusaiban történő adszorpciós folyamatok a törésmutatóban okoznak változást, és ezt a törésmutató változást $(\Delta \mathrm{n})$ használjuk fel az adszorbeált mennyiség meghatározására. Az elmúlt évek során csoportunk

\footnotetext{
* Csapó Edit. Tel.: +36-62-544-476; fax: +36-62-546-482; e-mail: juhaszne.csapo.edit@med.u-szeged.hu
} 
számos publikációt közölt félvezető nanorészecskék (főként $\mathrm{ZnO}_{2}, \mathrm{ZnO}$ ) és anionos polielektrolitok (polisztirolszulfonát, PSS és poliakrilsav, PAA) alkalmazásával készített hibrid vékonyrétegek jellemzésével, és azok szenzorikai alkalmazásával kapcsolatosan ${ }^{1-3}$, ezek közül a legutóbbit mutatjuk be röviden.

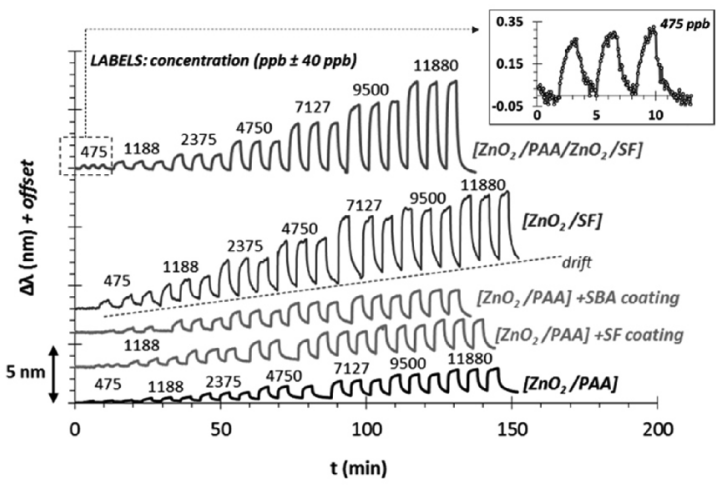

2. Ábra. $\mathrm{ZnO}_{2}$ nanorészecskék, PAA polielektrolit és mezopórusos szerkezetü $\mathrm{SiO}_{2}$ (SF, silica foam) egységek felhasználásával készített vékonyréteget, mint érzékelő felületet alkalmazó etil-alkohol szenzorok válaszai különböző mértékű EtOH koncentrációk esetében.

Egy potenciális etanol szenzor fejlesztése során $\mathrm{ZnO}_{2}$ nanorészecskék, PAA polielektrolit és mezopórusos szerkezetü $\mathrm{SiO}_{2}$ ( $\mathrm{SF}$, silica foam) egységek felhasználásával készítettünk különböző összetételü, érzékelő felületként szolgáló vékonyrétegeket. Amint az 1.A ábrán látható, ezek hússzoros $\mathrm{ZnO}_{2} / \mathrm{PAA}$ vagy $\mathrm{ZnO}_{2} / \mathrm{SF}$ kettösrétegböl, illetve tízszeres $\mathrm{ZnO}_{2} / \mathrm{PAA} / \mathrm{ZnO}_{2} / \mathrm{SF}$ hibrid egységböl épülnek fel. Etil-alkohol detektálási kísérleteink során azt tapasztaltuk, hogy a $\left[\mathrm{ZnO}_{2} / \mathrm{PAA}\right]_{20}$ felület elenyésző mértékü választ adott, fóként az alacsonyabb koncentrációk tartományában; a másik kettő, előnyösebb intenzitású válasz jelet adó szenzor közül a $\left[\mathrm{ZnO}_{2} / \mathrm{PAA}\right]_{20}$ jelentős alapvonal emelkedéssel (drift) volt terhelve, és magas koncentrációk esetében a válasz egyre inkább eltért a lineáristól. Ezzel szemben a $\left[\mathrm{ZnO}_{2} / \mathrm{PAA} / \mathrm{ZnO}_{2} / \mathrm{SF}\right]_{10}$ szerkezet válasza a teljes (0,475-11,88 ppm) koncentráció tartományon lineáris volt, alapvonal emelkedés nélkül. Számításaink szerint a szenzor kimutatási határa (limit of detection) LOD $<500$ ppb, amely érték magasan kiemelkedik a szobahőmérsékleten müködő etanol szenzorok sorából $1^{4}$.

\section{Görbült folyadék - folyadék határfelületek: Felület- aktív anyagok keverékeivel stabilizált nanoemulziók előállítása és olajipari alkalmazása}

A kutatócsoport müködése óta szinte folyamatosan végez ipari partnerektől érkező felkérés útján alkalmazott kutatásokat. Ezen innovatív kutatások során a csoportra jellemző klasszikus kolloidkémiai tudásbázisra építve, olyan területeken folynak vizsgálatok, mint például az asszociációs kolloidok fizikai-kémiai sajátságainak megismerése vagy a felületaktív anyagok határfelületi önrendeződését alapvetően meghatározó törvényszerüségek feltérképezése. Kutatási feladataink között megjelentek továbbá a görbült határfelülettel elválasztott folyadékfázisok alkotta emulziók optikai, szerkezeti és folyási (reológiai) tulajdonságai közötti összefüggésesek felderítésére és nem utolsó sorban a nemesfém nanorészecskék és ötvözeteik továbbá a hibrid struktúrák szintézismódszereinek optimalizálására irányuló vizsgálatok.

Az emulziók évtizedek óta fontos szerepet töltenek be az iparban és egészségügyben egyaránt. Számos termék elöállítása során alkalmaznak emulziókat és az előállított termékek jelentős része valamilyen emulzió. Ezért rendkívül fontos tulajdonságaik megismerése, a keletkezésüket és megszünésüket meghatározó paraméterek feltérképezése és tervezett szabályozása. A sokrétü felhasználás miatt az emulziókkal szemben támasztott követelmények meglehetősen eltérőek lehetnek. Az előállításuk vagy megszüntetésük során jelentkező költségeinek csökkentése és az alkalmazott technológiák egyszerüsítése azonban minden területen egyaránt lényeges. Továbbá, az alkalmazott eljárásoknak és anyagoknak egyre szigorúbb környezetvédelmi szabályozásnak kell megfelelniük. A nanométeres mérettartományba eső cseppeket tartalmazó emulziók iránti érdeklődés az 1980-as évektől kezdve egyre jelentősebbé vált. A már ismert és alkalmazott makro- és mikro-emulziókkal szemben a rendkívül kis cseppméretnek köszönhetően ezek a kolloid rendszerek további előnyős tulajdonságokkal rendelkeznek. Hatóanyag formulázásra alkalmas sajátságuk révén megjelentek gyógyszerészeti készítmények, kozmetikai cikkek és élelmiszeripari termékek fejlesztésében, valamint a müanyag- és petrolkémiai kutatásokban. Volumenét és globális jellegét tekintve különlegesen jelentős felhasználási területet képvisel az olajipar, amelyben hosszú ideje alkalmaz emulziókat.

A kőolaj kitermelésben folytonosan zajlanak kutatások a másodlagos müvelés után visszamaradt olajkészletek kiaknázására. Az olajipari gyakorlatban ezeket az olaj kitermelési módszereket az angol Enhanced Oil Recovery rövidítése után EOR-művelésnek nevezik. A gyakorlatban a termikus eljárások és különböző típusú gázok (általában szén-dioxid) besajtolásán kívül a felületaktív anyag- vagy polimer-oldatok alkalmazása terjedt el leginkább. Jelenleg a világ kőolaj termelésének mintegy 3,5\%-a származik a kőolajkihozatal-növelő EOR-eljárásokból. Az olajipar vezető nagyhatalma, az Amerikai Egyesült Államok jelenlegi kőolajtermelésének 12\%-át kőolajkihozatal-növelő eljárással termeli. Magyarország 1,3 millió tonnás éves olajtermelésének $17 \%$-a származik a megnövelt hatékonyságú módszerekből. A nanoemulziók egyik lehetséges olajipari felhasználása az olajkitermelésben alkalmazott vegyi anyagok szállítása/tárolása és azok irányított célba juttatása. A belső, emulgeált fázisban oldott anyagok nem kerülnek kapcsolatba a szállításra és tárolásra használt berendezésekkel, ezáltal például korrozív tulajdonságú anyagok is könnyedén célba juttathatók. A kutakban és vezetékekben keletkező káros lerakódás eltávolítása így a szerkezeti anyagok károsodása nélkül oldható meg. Az emulgeált fázis rendkívül nagy fajlagos felületének köszönhetően a nanoemulziók sokkal nagyobb mennyiségü felületaktív anyag szállítására és tárolására képesek, mint a vizes vagy oldószeres oldatok, amelyek esetén problémát jelent a felületaktív anyag oldhatósága ezáltal ezek a kolloid rendszerek a kútkarbantartáson és 
rétegkezelésen túlmenően a kőolajkihozatal-növelésében is hatékony eszközök lehetnek. Az emulziók és ezáltal a nanoemulziók is akkor keletkezhetnek, amikor elegendő energiát biztosítunk (pl. mechanikai energia formájában) a diszpergált fázis kialakulásával járó nagyobb határfelület létrehozásához. Mivel az emulzió képződés szabadentalpiája arányos a határfelületi feszültséggel, egy adott keverési energiánál, annál kisebb lesz az átlagos csepp méret, minél kisebb a határfelületi feszültség. A kis átméröjü cseppek létrehozása tehát nagy energiát és/vagy határfelületi feszültség csökkentő felületaktív anyagot igényel.

A felületaktív anyagok, más néven tenzidek, amfipatikus jellegü vegyületek, melyek egy hosszabb szénláncú hidrofób csoportot és hidrofil atomcsoportot tartalmaznak, amelyek eltérő aránya révén aszimmetrikus polaritás jellemzi a molekulát. Az eltérő polaritásnak köszönhetően ezek a molekulák a határfelületen úgy orientálódnak, hogy az apoláros molekularész fordul az apoláros fázis, a poláros fejcsoport pedig a poláros fázis felé. A határfelületi fázisban való feldúsulásuknak és speciális elhelyezkedésüknek köszönhetően a felületaktív anyagok csökkentik a határfelületi feszültséget, ezáltal képesek az emulziók keletkezését elősegíteni és a létrejövő diszperz rendszert stabilizálni. Az oldat töménységét növelve a határfelületen lévő tenzidmolekulák száma növekszik, és elérhető egy olyan koncentráció, melynél a felületaktív molekulák teljesen kiszorítják az oldószer molekuláit, a felületi feszültség ebben az esetben lesz a legkisebb. A tenzidkoncentrációt tovább növelve a felületi feszültség már nem vagy csak kis mértékben változik, azonban a folyadékban a tenzid molekulák asszociálódnak, micellák képződnek.

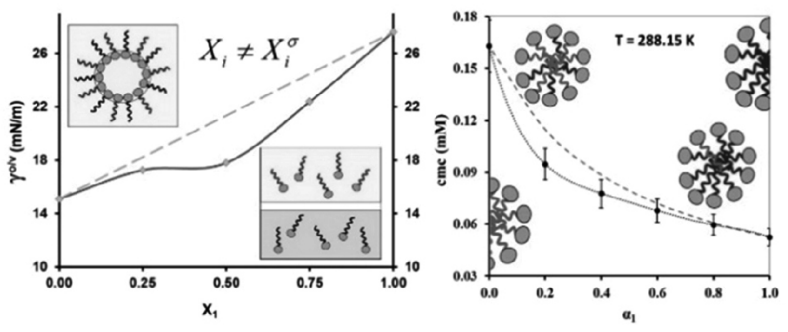

3. Ábra. A határfelületi feszültség és a kritikus micellaképződési koncentráció változása a tenzidkeverék összetételének függvényében

Adott koncentrációjú, de eltérő kémiai szerkezetű tenzideket tartalmazó oldat esetében a feldúsulás révén kialakuló felületi- vagy határfelületi feszültség az anyagi minőségeken és a hőmérsékleten túl a felületaktív anyagok egymáshoz viszonyított arányának is függvénye. Ennek megfelelően a tenzidkeverékek oldatainak esetében olyan adszorpciós azeotróp sajátság figyelhető meg, amely az elegyadszorpció tekintetében már régóta jól ismert jelenség. Az összetétel variálása mellett meghatározható azon összetételi arány, amely esetén a határfelületi réteg összetétele a legnagyobb mértékben eltér az ideális viselkedést feltételező számítás által jósolt értéktől ${ }^{5}$. Ezzel együtt ezen összetétel egyúttal minimummal rendelkezik a határfelületi szabadenergia tekintetébe, így meghatározása révén alacsony cseppméretü és jelentős kinetikai állandósággal bíró nanoemulzió állítható elő. A MOL Nyrt. megbízása révén indított
„Nanoemulziók olajipari alkalmazhatóságának vizsgálata" címü kutatási téma sikerességét jelzi, hogy 2013. év decemberében, majd 2015. novemberében a battonyai olajmező mészmárga tárlókőzetében végeztek el sikeres rétegserkentési müveleteket, amelyekhez a kutatócsoport és a cég munkatársai által közösen fejlesztett nanoemulziós technológiát alkalmazták.

\section{Szilárd - folyadék határfelületek: Kolloidális gyógyszer- hordozók, biomimetikus szenzorok és intelligens bevonatok}

\subsection{Felületi plazmon rezonancia vizsgálatok modell peptid/kismolekula kölcsönhatás tanulmányozására}

A mag-héj szerkezetü gyógyszerhordozó rendszerek szintézise és fizikai-kémiai méréstechnikákkal történő jellemzése az MTA által támogatott csoportunk egy meghatározó jelentőségü kutatási területe. A kolloidális hordozók mátrixaként szervetlen ${ }^{6}$ (pl. szilika, réteges kettős hidroxid) és szerves vegyületeket ${ }^{7}$ (pl. fehérjék, liposzómák) egyaránt alkalmazunk. A modell molekulaként felhasznált ibuprofen, ketoprofen sejtmembránokon való bevitelének biztosítása céljából a hatóanyagokat fehérje/polielektrolit mag-héj kompozitok szerkezetébe zárjuk. Meghatározzuk a hatóanyag kioldódás kinetikáját és kioldódási profilok ismeretében javaslatot tettünk a folyamat mechanizmusára ${ }^{8}$. A mag-héj kompozitok alkalmasak a hatóanyagok vér-agy gáton való átvitelére is, ezért a kompozitok neuroprotektív anyagok felszívódását is elősegítik. Együttmüködve a MTA-SZTE Idegtudományi Kutatócsoportjával a hidrofób karakterü kinurénsav kapszulázását oldottuk meg sikeresen, majd a módszer hatékonyságát in vitro modell vér-agy gátas ill. in vivo állatkísérletek is igazoltunk. ${ }^{9}$ A technológia gyógyszeripari alkalmazására 2015-ben eljárási szabadalmat nyújtottunk be a fehérje/hatóanyag kompozit témájában, amelynek előállítási sémáját a 4 . ábra szemlélteti.

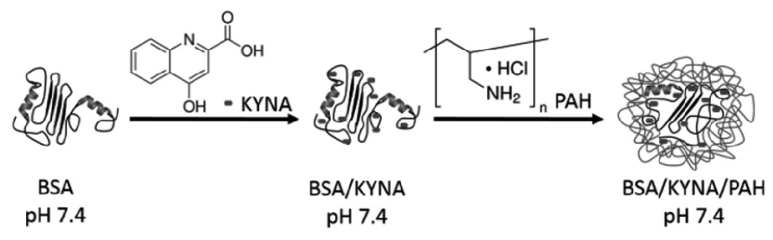

4. Ábra. A BSA/KYNA/PAH nanokapszula előállításának sematikus ábrája

Kisszögü röntgenszórás (SAXS) valamint infravötrös (FT-IR) és cirkuláris dikroizmus (CD) spektroszkópa módszerével végzett szerkezetvizsgálat útján sikeresen detektáltuk a proteinek konformációjának változását a $\mathrm{pH}$ függvényében a hatóanyag megkötődése előtt és után. ${ }^{8} \mathrm{~A}$ mag-héj szerkezetü kompozitokban a komponensek közötti receptor-ligandum jelelgü kölcsönhatásokat a felületi plazmon rezonancia (SPR) és izoterm titrációs kalorimetria (ITC) módszerének alkalmazásával kvantitatív módon jellemeztük. $^{8}$

Az elmúlt évtizedek során az SPR spektroszkópia módszere egyre szélesebb teret hódított az élettani jelentőségü kölcsönhatások modellezésben és vizsgálatában. A kvázi kétdimenziós analitikai eljárás segítségével elsősorban 
fehérjék közötti kölcsönhatások mennyiségi és minőségi analízise végezhető el. A módszer kiválóan alkalmas a biológiai folyamatok vizsgálatára, felbontásának, érzékenyégének és minimális minta igényének köszönhetően. Míg a korábban-e célra alkalmazott vizsgálati módszerek, mint például a kvarc kristály mikromérleg (QCM) anyagigénye viszonylag nagy lehet, költségessé téve ezzel a kérdéses rendszer vizsgálatát, az SPR spektroszkópia képes rendkívül alacsony (fehérjék esetében akár nM-os) koncentráció tartományban is mérni. A vizsgálati módszer további pozitívuma, hogy a kölcsönható partnerek koncentráció változását, valós időben és jelölőanyag használata nélkül is lehet detektálni. A leggyakrabban vizsgált kölcsönhatások a DNS-DNS, DNS-RNS, DNS-fehérje, lipid kettősréteg-fehérje, fehérje/peptidgyógyszer molekulák között kialakuló kötéstípusok.

A módszer alapját képző jelenségét a Johns Hopkins Egyetem kutatója R. M. Wood figyelte meg elsőként, a diffrakciós rácson szórt fény spektrumában megjelenő anomáliával kapcsolatban. Később bizonyításra került, hogy a kérdéses anomáliák kapcsolatban állnak a rács felületén létrejövő elektromágneses felületi hullámok gerjesztésével és a visszavert fény intenzitásának csökkenése a gerjesztett felületi plazmonok hatása. A plazmon rezonancia a fémben lévő vezetési elektronoknak az elektromágneses tér segítségével gerjesztett hullámszerü mozgását jelenti, amely hatására a fémfelület és a dielektrikum határán a határfelülethez közel erős, de egyben erősen csillapított tér alakul ki. A felületi plazmon rezonancia analitikai célú alkalmazása során az egyik kölcsönható felet a nemesfém bevonatú szenzor felületre rögzítik (immobilizálás), ez leggyakrabban a nagyobb moláris tömegü molekula (receptor), de a rögzítés számos tényező, úgymint a koncentráció vagy a minta összetételének is függvénye. A másik kölcsönható molekula (analit/ligandum) adott koncentrációjú vizes oldatát a szenzor felülete felett áramoltatják állandó sebességgel, lehetővé téve a két fél közötti interakció létrejöttét. Az immobilizálás megtörténhet kovalens kötéssel közvetlenül az arany bevonatú chip felületén, ha a biomolekula tartalmaz a kötés kialítására alkalmas tiolcsoportot. A mérés során a chipet a hordozó oldaláról a teljes visszaverődés szögén belül, de széles beeső szög tartományban monokromatikus fénnyel világítják meg, amely az üveg felső határán teljes visszaverődést szenved, majd a visszavert sugár egy detektorra vetődik. A teljes visszaverődés során az elektromágneses hullám exponenciálisan csökkenő intenzitással behatol (ezáltal evaneszcens tér alakul ki) a szenzor mintakamrájának oldalán lévő közegbe. Az evaneszcens tér kiterjedése a fémrétegre és fölötte lévő keskeny, néhány száz nanométer vastag tartományra korlátozódik. A beeső fény egy bizonyos szög (vagy hullámhossz) mellett kölcsönhatásba lép a fémrétegben lévő szabad elektronokkal és az általuk létrehozott elektromágneses térrel, és rezgésbe hozza, gerjeszti azokat, vagyis kialakul a felszíni plazmon rezonancia. Ekkor az adott beesési szöghöz (vagy hullámhosszhoz) tartozó fény elnyelődik, intenzitása csökken, ahogyan azt az 5.a ábra szemlélteti. Alkalmasan megválasztott detektor segítségével meghatározhatjuk az intenzitás minimumhoz tartozó szöget vagy hullámhosszat.

A szenzor felszínéhez kötődő molekulák megváltoztatják az evaneszcens térben a lokális törésmutatót, amely hatással van a plazmon hullámok rezonancia feltételeire, a kötődés során a rezonanciához tartozó szög vagy hullámhossz eltolódik. Az eltolódás mértéke (fehérjék esetében jó közelítéssel egyenesen) arányos a felszínen megkötődő anyagmennyiséggel. Ezáltal pontosan meghatározható tehát egy kísérleti rendszeren belül a szenzorfelületen megkötött receptor jellegű makromolekula anyagmennyisége. ${ }^{10} \mathrm{Az}$ irreverzibilisen kötött receptor által funkcionalizált szenzorfelület ezután alkalmas a kérdéses ligandum megkötődésének vizsgálatára.
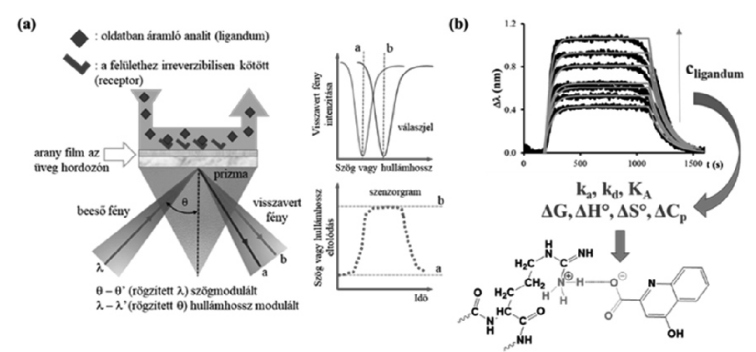

5. Ábra. Az SPR mérési elvének bemutatása (a) illetve a regisztrált szenzorgramok kinetikai modellekkel történő illesztése révén meghatározható kinetikai és termodinamikai paraméterek meghatározhatósága (b).

A kölcsönható pár mennyiségi viszonyainak megállapításán túl a megfelelö adatfeldolgozási és kiértékelési eljárás kidolgozása után a folyamat sebességi és egyensúlyi állandói is meghatározhatóak. Mindezen paraméterek hőmérsékletfüggésének tanulmányozása révén számíthatóvá válnak azon termodinamikai állapotfüggvények, melyek megerősíthetik egy feltételezett kapcsolódási mechanizmus helyességét. Az így származtatott termodinamikai adatok a független izoterm titrációs mikrokalorimetriás mérés által szolgáltatott entalpia adatokkal összevethetők.

Az említett idegtudományi kutatócsoporttal folytatott kinurénsav központú kutatás során az említett potenciális hatóanyag szorpciós izotermáinak meghatározását végeztük el az AMPA (alfa-amino-3-hidroxi-5-metil-4-isoxazolpropionsav) receptor $\mathrm{GluR}_{1}$ (glutamát receptor) alegységet modellezö peptid fragmensekkel funkcionalizált ${ }^{11}$ SPR szenzorfelületen. Egy kiválasztott fragmens $\left(\right.$ GluR $\left._{1,270-300}\right)$ esetében a szenzorgramok kinetikai modell alapján történő diszkrét és globális illesztése révén, meghatároztuk a hatóanyag megkötődésének sebességi és egyensúlyi állandót, majd ezek birtokában javaslatot tettünk az alegységhez történő kötődés módjára. A kérdéses receptor alegységhez történő kötődés specifikus jellegének igazolására összehasonlító vizsgálatokat végeztünk szérum albumin fehérjék receptorként való alkalmazásával. A receptor modellek és szérum fehérjék alkalmazásával végezett SPR spektroszkópiás mérések eredményeinek összevetése megerősítette a feltételezett kötési módot valamint annak specifikusságát. ${ }^{12,13}$ 


\subsection{Biofunkcionalizált plazmonikus és fluoreszcens arany nanorészecskék/nanoklaszterek}

A fiziológiás körülmények között is jelentős kolloid stabilitást mutató fehérjék az 5-10 nanométeres mérettartományba sorolhatók, ezáltal kolloid sajátságaik vizsgálata tematikailag a nanoszerkezetü anyagok kutatásához kapcsolódik. A kutatócsoportban számos, nemzetközileg rangos folyóiratokban közöltük az arany és ezüst kolloidok méretszabályozott előállításáról szóló tudományos eredményeinket, ahol a vizes közegü nemesfém szolok stabilitásának növelésére a konvencionálisan alkalmazott felületaktív anyagokon és polimereken túl aminosavakat, kis molekulatömegü peptideket, ill. fehérjéket használtunk. ${ }^{14-16}$ A nevezett rendszerek egyedi részecskéinek alakjával, méretével, szerkezetével és anyagi minőségével szisztematikusan hangolható, optikai (lokalizált felületi plazmon rezonancia, LSPR) tulajdonságait tanulmányoztuk. Sikeresen elöállítottunk és karakterizáltunk arany/ezüst ötvözet és rúd alakú arany nanorészecskéket, melyek esetén az összetétel és a morfológia módosításával a plazmonikus tulajdonságok hangolhatóvá válnak. ${ }^{17,18} \mathrm{~A}$ nanoméretű fém részecskék felületének funkcionalizálása révén a plazmonikus részecskék által növelt fluoreszcencia (plasmon-enhanced fluorescence) tanulmányozható, mely az optikai bioszenzorok fejlesztésének egyik meghatározó jelensége. ${ }^{19}$

(a)
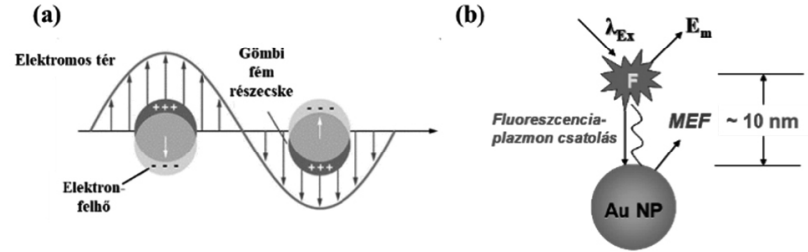

6. Ábra. A felületi plazmon rezonancia (a) és a plazmonikus fém által növelt fluoreszcencia (b) jelenségek.

Az említett optikai sajátságok közül 6. ábra a felületi plazmon rezonancia és a plazmonikus fém által növelt fluoreszencia jelenség alapjait mutatja be, míg a 7. ábra a szférikus arany és ezüst, valamint különböző hossz/szélesség arányú rúd alakú arany részecskék egyedi plazmon sávjait jeleníti meg.

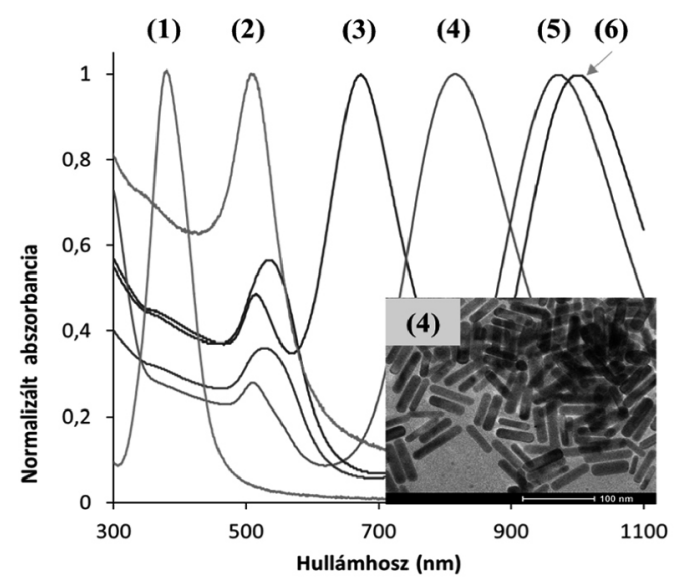

7. Ábra. A gömb alakú Ag (1: 390 nm), gömb alakú Au (2: 518 nm) és rúd alakú Au részecskék egyedi plazmon rezonancia sávjai a 4. sorszámú diszperzió TEM felvételével (3: $682 \mathrm{~nm}: \mathrm{AR}=2,5 ; \mathbf{4}: 825 \mathrm{~nm}: \mathrm{AR}=4,4 ; \mathbf{5}$ : $980 \mathrm{~nm}: \mathrm{AR}=5,0 ; \mathbf{6}: 1015 \mathrm{~nm}: \mathrm{AR}=5,2)$.
A nemesfém kolloidok szerkezet és stabilitásvizsgálatán túl az elmúlt években egyre intenzívebben foglalkozunk aminosavakkal, fehérjékkel és nukleotidokkal stabilizált fluoreszcens sajátsággal rendelkező nemesfém alapú nanoklaszterek előállításával, karakterizálásával valamint szenzorikai felhasználásával. ${ }^{19,20}$ A klaszterek emissziós sajátsága és a klasztert felépítő atomok száma közötti kapcsolat alapján az 5-8 atomból álló klaszterek a kék (450-470 nm), míg a 12-15 atomból állók a zöld (500-520 nm) tartományban emittálnak. Analitikai célú alkalmazásokban rendkívül ígéretesek az AMP (adenozin-monofoszfát) molekulák által stabilizált arany nanoklaszterek, amelyeket $\mathrm{Fe}^{3+}$-ionok vizes közegben történő szelektív kimutatására sikeresen alkalmaztuk. ${ }^{20}$ Mindezek mellett szervetlen anionok vagy egyéb biomolekulák detektálására, szelektív feldúsulásuk esetén fluoreszcens képalkotásra vagy különböző hatóanyag szállító rendszerek jelölésére is kiválóan alkalmasak lehetnek, így a jövőbeli kutatásoknak is szerves részét fogják képezni.

\subsection{Szuperhidrofób, oleofób és fotoreaktív felületek}

Szabályozott összetételű és hangolható tulajdonságokkal rendelkező nanoszerkezetű rendszerek előállításával új funkcionális anyagokat és intelligens bevonatokat hozhatunk létre. ${ }^{21}$ Ezek a több komponensü nanostrukturált rendszerek értékes információt adhatnak, ill. elönyösen használhatóak mindazon kutatási területeken, ahol a határfelületi jelenségeknek szerepe nem hanyagolható el. Ide sorolandó minden olyan fejlesztés, amelynek célja korszerü és hatékony (foto)katalizátor, szenzor, napelem előállítása által szennyezőanyagok ártalmatlanítása és detektálása vagy a megújuló energiaforrások kiaknázása. Az természet által ihletett, biomimetikus technológiai megoldások alapjait is nagyon gyakran a kolloidkémiai szintézismódszerekkel kialakított speciális határfelületek, ill. határfelületi jelenségek alkotják. Ennek jól ismert példája az öntisztuló tulajdonságú lótuszlevél finomszerkezetének mesterséges kialakítása. A növény levelét és virágát a víz és más folyadékok nem nedvesítik, olyan csepp képződik rajtuk, amely nem tapad meg annak felületén, hanem lepereg arról, sőt közben a növényen található szennyeződéseket is eltávolítja. Ennek megfelelően a hasonló mikrométeres és nanométeres skálán strukturált mesterségeses felületek is vízlepergető és öntisztuló tulajdonságokkal bírnak. ${ }^{22} \mathrm{Az}$ öntisztuló felületek egy másik nagy csoportját a katalitikus tulajdonságokkal rendelkező vékonyrétegek képviselik. Ezek preparálásával valamint környezetvédelmi, egészségügyi, mikrobiológiai és orvos biológiai alkalmazási lehetőségeinek felkutatásával munkacsoportunk évek óta foglalkozik. ${ }^{23,24} \mathrm{Az}$ ilyen katalitikus bevonatok alkalmazása esetén a megfelelő hullámhosszúságú elektromágneses sugárzás gerjeszteni képes a felületen immobilizált félvezető oxid alapú fotokatalizátor részecskéket (pl. $\mathrm{TiO}_{2}$, vagy $\mathrm{ZnO}$ ), amely hatására reaktív specieszek keletkeznek. Ezek a reaktív gyökök /pl. szuperoxid $\left(\mathrm{O}_{2}^{-}\right)$hidrogén- peroxid $\left(\mathrm{H}_{2} \mathrm{O}_{2}\right)$, vagy hidroxil- gyök $\left({ }^{\mathrm{HO}}\right) /$ megfelelően nagy oxidációs potenciállal rendelkeznek ahhoz, hogy a különböző szerves anyagokat lebontsák. Reaktív tulajdonságaiknak köszönhetően felhasználhatók szennyező 
gázok, gőzök és aeroszolok fotodegradációjára valamint felületek fertőtlenítésére egyaránt. ${ }^{24}$ A katalitikus részecskék felületi immobilizálása polimerekkel alkalmazásával valósítható meg, amely esetben a polimer rögzítő anyag nem kívánt fotodegradációja egy inert lamellás szerkezetű adalékkal jelentős mértékben visszaszorítható. Kutatásaink során bizonyítottuk, hogy az említett kedvező hatáson túlmenően a szervetlen hidroxiapatit lamellák nagyobb diszperzitásfokot biztosítanak a $\mathrm{TiO}_{2}$ fotokatalizátor részecskéknek, ezáltal a kompozit katalizátor fotokatalitikus hatásfoka jelentős mértékben növekedhet. ${ }^{25}$

Munkacsoportunkban az öntisztuló felületek és a fotokatalizátorok elönyös tulajdonságát ötvöztük ${ }^{22}$, olyan rétegek kialakítása során, amelyek egyszerre mutatnak szuperhidrofób és katalitikus tulajdonságokat (8. ábra). Szintézisük során felhasználjuk az őket felépítő mindhárom kolloid rendszer előnyös tulajdonságait. A kis felületi energiával rendelkező polimer kötőanyag érdességét látható fényben aktív plazmonikus fotokatalizátor nanorészecskék alkalmazásával növeljük. A nagy felületi energiával rendelkező nanorészecskék és a hidrofób polimer társíthatóságát (a részecskék polimer filmben történö eloszlathatóságát) pedig a felületükön adszorbeált tenzid molekulák alkalmazásával biztosítottuk. A réteg kialakítása során a primer fotokatalizátor nanorészecskék mikrométeres nagyságrendbe eső aggregátumokat alkotnak (8.a ábra). Így a kialakult bevonat - hasonlóan a természetes eredetü lótuszlevél finom struktúrájához- mind mikro- mind nanoszinten strukturált, érdes jelleget mutatnak.

a.)
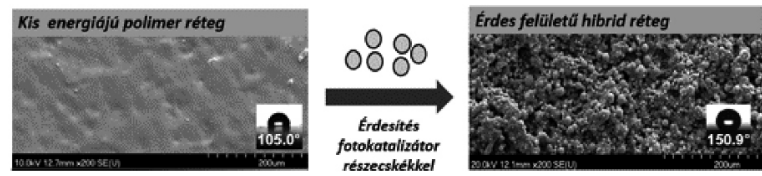

b.)

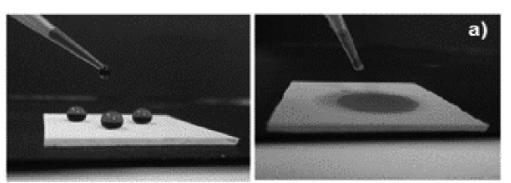

c.)

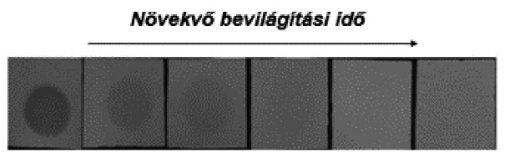

8. Ábra. A fotoreaktív és szuperhidrofób bifunkciós tulajdonsággal rendelkező hibrid réteg SEM felvételei (a). A metilénkék oldat nem nedvesíti a filmet, még az apoláros vörös színủ (szudán IV) festékoldat szétterül a rétegen (b), majd ezt követően fotodegradációt szenved (c)

A polimer kötőanyag hidrofilitásának változtatásával elérhető, hogy a kialakított fotoreaktív rétegek nedvesedése széles skálán, a szuperhidrofiltől egészen a szuperhidrofób tulajdonságig változzon. A makromolekulás rendszerek jól tervezhető anyagok, szintéziskörülményeik paraméteri által szabályozható tulajdonságokkal ruházhatók fel. A szabályozható nedvesedést például egy hidrofil és hidrofób monomer kopolimerizációjával előállított akril- alapú polimer vékonyréteg biztosítja.

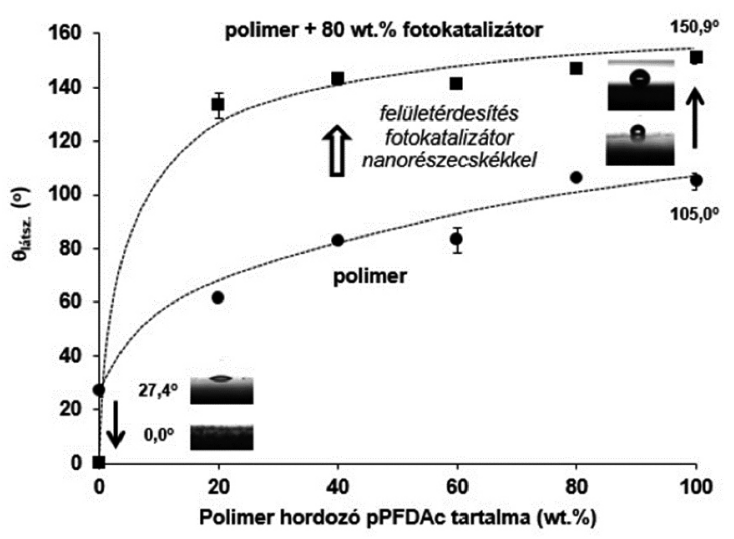

9. Ábra. A kopolimer hidrofilitásának hatása a kiindulási polimer filmek, ill. a fotokatalizátor részecskékkel érdesített hibrid vékonyrétegek nedvesedési tulajdonságaira

A plazmonikus fotokatalizátor részecskék által érdesített hibrid film esetében pedig a felületi érdesség a felület jellegét, azaz nedvesedési tulajdonságait fokozza (9. ábra). A tetszőleges nedvesedési tulajdonságú és egyben fotoreaktív réteg alapú technológiai megoldásokat több ipari partnerrel együtt kutatjuk, az olajipar alkalmazásoktól az ipari és lakossági vízkezelésben való felhasználásig.

\section{Összefoglalás}

A Szegedi Tudományegyetemen közel 25 éves múltra visszatekintő Kolloidok és Nanoszerkezetü Anyagok Kutatócsoport klasszikus kolloid kémiai tudásbázisra építkezve az elmúlt évtizedek során sikeresen folytatott korszerü és eredményes alap- és alkalmazott kutatásokat. Rangos nemzetközi folyóiratokban kerültek bemutatásra a szenzorfejlesztésben alkalmazott polielektrolit, félvezető és agyagásvány alapú filmek és vékonyrétegek, valamint a funkcionalizált nemesfém alapú felületek és részecskék és nem utolsó sorban a fluoreszcens sajátságú arany nanoklaszterek. Nemzetközi viszonylatban már rendkívül széles körben alkalmazott méréstechnikák megismerése és honosítása, valamint a csoportba integrált különböző tudományterületeken jártas kutatók révén korábban példátlan interdiszciplináris kutatások indulhattak. Ezek eredményei között a receptorok és potenciális hatóanyagok molekuláris léptékü kölcsönhatásának modellezésétől kezdve a fehérje alapú gyógyszerhordozó rendszerek tervezésén és szintézisén át a proteinek konformáció változásának követéséig számos területen születtek bemutatásra érdemes és a jövőben tovább hasznosítható eredmények. Ipari partnerektől érkező megbízások során a csoport olyan fejlesztésekben vett részt, amelyek egy része az alkalmazott kutatásból kifejlődve a léptéknövelt technológiai teszteken át mára ipari gyakorlattá vált és emellett nemzetközi iparjogi oltalom alatt áll.

\section{Köszönetnyilvánítás}

A közlemény az OTKA K116323 pályázat és a Bolyai János Kutatási Ösztöndíj támogatásával készült. A szerzők köszönetet mondanak az idézett cikkekben szereplö társszerzők, elsősorban Janóné Ungor Ditta Anita, Deák Ágota és Dr. Varga Noémi közreműködéséért. 11. 


\section{Hivatkozások}

1. Sebők, D.; Szabó, T.; Dékány, I.; Appl. Surf. Sci., 2009, 255, 6953-6962.

https://doi.org/10.1016/j.apsusc.2009.03.020

2. Sebők, D,; Csapó, E.; Ábrahám, N.; Dékány, I.; Appl. Surf. Sci., 2015, 333, 48-53.

https://doi.org/10.1016/j.apsusc.2015.01.150

3. Sebök, D.; Dékány, I.; Sensor. Actuat. B-Chem., 2015, 206, 435-442.

https://doi.org/10.1016/j.snb.2014.09.087

4. Sebők, D.; Janovák, L.; Kovács, D.; Sápi, A.; Dobó, D.G.; Kukovecz, Á.; Kónya, Z.; Dékány, I.; Sensor. Actuat. B-Chem., 2017, 243, 1205-1213.

https://doi.org/10.1016/j.snb.2016.12.097

5. Juhász, Á.; Tabajdi, R.; Dékány, I.; Csapó, E.; J Surfact Deterg., 2017, 21, x-x.

https://doi.org/10.1007/s11743-017-2025-x

6. Varga, N.; Benkő, M.; Sebők, D.; Bohus, G.; Janovák, L.; Dékány, I.; Microporous Mesoporous Mater., 2015, 213, 134-141. https://doi.org/10.1016/j.micromeso.2015.02.008

7. Benkő, M.; Varga, N.; Sebők, D.; Bohus, G.; Juhász, Á.; Dékány, I.; Colloids Surf. B., 2015, 130, 126-132. https://doi.org/10.1016/j.colsurfb.2015.04.018

8. Csapó, E.; Juhász, Á.; Varga, N.; Sebők, D.; Hornok, V.; Janovák, L.; Dékány, I.; Colloids Surf. A., 2016, 504, 471-478. https://doi.org/10.1016/j.colsurfa.2016.05.090

9. Varga, N.; Csapó, E.; Majláth, Z.; Ilisz, I.; Krizbai, I.A.; Wilhelm, I.; Knapp, L.; Toldi, J.; Vécsei, L.; Dékány, I.; Eur. J. Pharmac. Sci., 2016, 86, 67-74. https://doi.org/10.1016/j.ejps.2016.02.012

10. Csapó, E.; Majláth, Z.; Juhász, Á.; Roósz, B.; Hetényi, A.; Tóth, G.K.; Tajti, J.; Vécsei, L.; Dékány, I.; Colloids Surf. B., 2014, 123, 924-929.

https://doi.org/10.1016/j.colsurfb.2014.10.046

11. Csapó, E.; Bogár, F.; Juhász, Á.; Sebők, D.; Szolomájer, J.; Tóth, G.K.; Majláth, Z.; Vécsei, L.; Dékány, I.; Colloids Surf. B., 2015, 133, 66-72. https://doi.org/10.1016/j.colsurfb.2015.04.044

12. Juhász, Á.; Csapó, E.; Ungor, D.; Tóth, G.K.; Vécsei, L.; Dékány, I.; J. Phys. Chem. B.; 2016, 120 (32), 7844-7850. https://doi.org/10.1021/acs.jpcb.6b05682

13. Juhász, Á.; Csapó, E.; Vécsei, L.; Dékány, I.; Periodica Polytech., Chem.; 2017, 61 (1), 3-9.

https://doi.org/10.3311/PPch.10185
14. Csapó, E.; Patakfalvi, R.; Hornok, V.; Tóth, L.T.; Sipos, Á.; Szalai, A.; Csete, M.; Dékány I.; Colloids Surf. B., 2012, 98, 43-49. https://doi.org/10.1016/j.colsurfb.2012.03.036

15. Csapó, E.; Sebők, D.; Babić, J.M.; Šupljika, F.; Bohus, G.; Dékány, I.; Kallay, N.; Preočanin, T.; J. Dispersion Sci. Technol., 2014, 35 (6), 815-825. https://doi.org/10.1080/01932691.2013.817314

16. Csapó, E.; Ungor, D.; Juhász, Á.; Tóth, G.K.; Dékány, I.; Colloids Surf. A., 2016, 511, 264-271. https://doi.org/10.1016/j.colsurfa.2016.10.003

17. Yang, Y.Y.; Csapó, E.; Zhang, Y.L.; Süßmann, F.; Stebbings, S.L.; Duan, X.M.; Zhao, Z.S.; Dékány, I.; Kling, M.F.; Plasmonics.; 2012, 7 (1), 99-106. https://doi.org/10.1007/s11468-011-9281-9

18. Csapó, E.; Oszkó, A.; Varga, E.; Juhász, Á.; Buzás, N.; Körösi, L.; Majzik, A.; Dékány, I.; Colloids Surf. A., 2016, 415, 281-287. https://doi.org/10.1016/j.colsurfa.2012.09.005

19. Csapó, E.; Ungor, D.; Kele, Z.; Baranyai, P.; Deák, A.; Juhász, Á.; Janovák, L.; Dékány I.; Colloids Surf. A., 2017, $532(5), 601-608$. https://doi.org/10.1016/j.colsurfa.2017.02.047

20. Ungor, D.; Csapó, E.; Kismárton, B.; Juhász, Á.; Dékány, I.; Colloids Surf. B., 2017, 155, 135-141. https://doi.org/10.1016/j.colsurfb.2017.04.013

21. Harmati, M.; Tarnai, Zs.; Decsi, G.;Kormondi,S.; Szegletes, Z.; Janovak, L.; Dekany, I.; Saydam, O.; Gyukity-Sebestyen, E.; Dobra, G.; Nagy, I.; Nagy, K.; Buzas, K.; Journal of Oral Pathology and Medicine, 2017, 46 (4), 259-266. https://doi.org/10.1111/jop.12486

22. Deák, Á.; Janovák, L.; Csapó, E.; Ungor, D.; Pálinkó, I.; Puskás, S.; Ördög, T.; Ricza, T.; Dékány, I.; Applied Surface Science, 2016, 389, 294-302. https://doi.org/10.1016/j.apsusc.2016.07.127

23. Veres, Á.; Rica, T.; Janovák L.; Dömök, M.; Buzas, N.; Zöllmer, V.; Seemann, T.; Richardt, A.; Dékány, I.; Catalysis Today, 2012, 181, 156-162. https://doi.org/10.1016/j.cattod.2011.05.028

24. Tallósy, Sz. P.; Janovák, L. Ménesi J.; Nagy, E.; Juhász, Á.; Balázs, L.; Deme, I.; Buzás, N.; Dékány, I.; Environmental Science and Pollution Research, 2014, 21 (19), 11155-11167. https://doi.org/10.1007/s11356-014-2568-6

25. Janovák, L; Deák, Á.; Tallósy Sz.P.; Sebők, D.; Csapó, E.; Bohinc, K.; Abram, A.; Pálinkó, I.; Dékány, I.; Surface \& Coatings Technology, 2017, 326, 316-326. https://doi.org/10.1016/j.surfcoat.2017.07.072

\section{Application of nanostructured materials in sensor development, oilfield chemistry, drug discovery and heterogeneous catalysis}

Protein-biomolecule/drug molecule interactions play a determinant role in biological systems. Detailed quantitative, kinetic and thermodynamic characterization of these biomolecular interactions may decisively contribute to the modern pharmaceutical developments. Numerous different analysis are available that can be used to monitor and quantify these bindings. However the radio-labelled assays for labelling of either the protein or the biomolecule are fast and reproducible techniques, their major disadvantages are that they are hazardous to human health; produce radioactive waste and require special laboratory conditions. This has led to the development of "label-free" assays based on optical (e.g. colorimetric, fluorescence or chemo-/bioluminescence) methods. The well-known two-dimensional (2D) sensor techniques especially the surface plasmon resonance (SPR), optical waveguide lightmode spectroscopy (OWLS), the quartz crystal microbalance (QCM) or the polarized reflectometric interference spectroscopy (PRIfS) are capable of real-time monitoring of these interactions without the use of labels. However, numerous research group utilize the SPR technique to investigate biomolecular interactions in real time but only a few articles give substantive information about the temperature-dependency of the biomolecular interactions. Investigation of temperature-dependent adsorption phenomena at solid/liquid interface permits the determination of thermodynamic state functions $\left(\Delta \mathrm{G}, \Delta \mathrm{H}^{\circ}\right.$, $\Delta \mathrm{S}^{\circ}$ ) of the interaction. The knowledge of these classic physical-chemical parameters is crucial for drug 
development. In previous work we successfully combined the beneficial sensing properties of mesoporous silica materials and reflectometric interference technique to construct a highly sensitive ethanol sensor operating at room temperature. The three types of hybrid thin films, namely $\mathrm{ZnO} 2 /$ polyelectrolyte (PAA), $\mathrm{ZnO} 2 /$ mesoporous silica foam (SF) and a mixed, $\mathrm{ZnO} 2 / \mathrm{PAA} / \mathrm{ZnO} 2 / \mathrm{SF}$ structures were subjected to sensorial tests in the gas phase. We showed that the detection limit of the sensor is sub-ppm $(<500 \mathrm{ppb})$, but only the mixed $(\mathrm{ZnO} 2 / \mathrm{PAA} / \mathrm{ZnO} 2 / \mathrm{SF})$ nanostructure showed linear sensitivity in the 0.4-11.9 ppm range without response drift, while both the response time and selectivity remain reasonable good. Besides the investigations of solid/gas interfaces, the molecular interactions between different glutamate receptor model peptides (GluR1201-230, GluR1231-259 and GluR1270-300) and kynurenic acid (KYNA) have also been studied by SPR experiments at solid/liquid interfaces. The studied system is specifically relevant in the neuroscience. Understanding the exact molecular mechanism of the action of KYNA on AMPARs might promote future drug development for the therapeutic management of these disorders. We established that the binding of kynurenic acid on peptide-functionalized gold surface is fully reversible. We measured the reversible bonded amount of KYNA molecules on different peptide-modified gold surface at different temperatures under physiological conditions. Because of the reversible interaction between KYNA and subunits of AMPA receptor the heat of sorption/binding values for KYNA at constant surface loading can be quantitatively determined. The registered sensorgrams were fitted by different kinetic model in order to provide important kinetic parameters of the KYNA binding on peptide surface. Besides the experimental characterization of the receptor-ligand systems the underlying molecular mechanism can be investigated using the methods of computational molecular modelling. On the other hand the above mentioned SPR techniques have been used to provide important information for the design of drug molecules-containing core-shell type nanocarrier composite systems as well. These core-shell nanoparticles (CSNPs) are widely used for therapy and diagnosis to deliver a drug in the right place at the right time in the adequate concentration.
The main biological requirements for the synthesis of CSNPs: utilization of biodegradable and biocompatible materials without immunogenic and thrombogenic features. The suitable CSNPs have a diameter below $100 \mathrm{~nm}$ and are stable in blood during prolonged circulation time. We have prepared different nanocarrier composite systems using albumin protein or inorganic silica and biocompatible polymers in order to encapsulate different neurotransmitter and non-steroidal anti-inflammatory (NSAIDs) drug molecules such as kynurenic acid and ibuprofen. For neurotransmitter-containing carrier systems the key question is the successful penetration of the nanocomposite across the blood brain barrier (BBB). Many potential therapeutic agent using in biological systems are limited namely they can't get through the BBB, this owing to their properties, for examples size, lipophilicity, charge, etc. This barrier could be eliminated by chemical modifications, interactions with other molecules or application of composites. Novel, carrier-systems in nanoscale may promote the drug delivery into the brain which give the possibility to treat the neurological disorders. For this purpose we have synthetized one-layered core-shell nanocomposite for delivery of kynurenic acid. Based on the results of in vitro and in vivo experiments this nanocarrier system may the future of brain drug development. We submitted a patent for this core-shell nanocomposite since this is able to deliver different drug molecules, especially neurotransmitters into the central nervous system (CNS).

Novel, plasmonic gold nanoparticles and sub-nanometer sized fluorescence gold nanoclusters have also been synthesized using biocompatible preparation method to visualize the delivery of drug candidates-containing nanocomposites and for following the structural and conformation change of proteins due to the binding of particles and clusters to the ligand or drug molecules. Chitosan- and BSA-based nanocomposites have been successfully labelled with blue-emitting $\mathrm{Au} / \mathrm{His}$ nanohybrid system. Moreover, the synthesized gold nanoclusters (adenosine-monophosphate (AMP)-stabilized red-emitting clusters) have been utilized for the development of selective sensor for detection of $\mathrm{Fe}^{3+}$-ions in aqueous solutions. 